\title{
DECREASED VEGF AND CYCLIN D1 GENES EXPRESSION ENHANCES CHEMOSENSITIVITY OF HUMAN SQUAMOUS CELL CARCINOMA CELLS TO 5-FLUOROURACIL AND/OR MESENCHYMAL STEM CELLS-DERIVED MICROVESICLES
}

\author{
Ghada A. Abd El Latif * Iman M. Aboushady ${ }^{* *}$ and Dina Sabry ${ }^{* * *}$
}

\begin{abstract}
Background: Among the most common oral cancers is oral squamous cell carcinoma which has high rates of mortality. 5-flurouracil (5-FU) is a widely used chemotherapeutic agent for treatment of head and neck cancers. However, its use has many limitations due to its well- known side effects. Thus, in the current study we aimed to investigate the chemosensitivity of squamous cell carcinoma cells to 5-FU and/or mesenchymal stem cells-derived microvesicles via H\&E histopathological examination, in addition to detection of vascular endothelial growth factor (VEGF) and cyclin D1 (CD1) genes' expression through quantitative RT-PCR analysis.
\end{abstract}

Material \& Methods: Human squamous cell carcinoma cell line (SCC152) was treated by 5-FU or Microvesicles or their combination for 24 and 48 hours. Histopathological examination through H\&E stain as well as quantitative RT-PCR analysis, for gene expression of VEGF and $\mathrm{CD} 1$, were performed. Finally, statistical analysis of the obtained data and correlation between VEGF and CD1 genes' expression among different groups were performed.

Results: Regarding the histopathological results, the combination group, as compared to 5-FU or microvesicles treated groups, showed the most obvious improvement where numerous apoptotic bodies were observed at $24 \mathrm{hrs}$, being markedly increased at $48 \mathrm{hrs}$ of culture, while viable cells were rarely seen. Concerning the qRT-PCR results, the combination group showed significant decrease in genes' expression of both VEGF and CD1 than the 5-FU or microvesicles treated groups. Furthermore, correlation between VEGF and CD1 genes' expression revealed a very good positive correlation.

Conclusions: it was concluded that the combined use of microvesicles and 5-FU resulted in enhanced chemosensitivity of squamous cell carcinoma cells more than the use of either 5-FU or microvesicle alone. In addition, down regulation of VEGF gene expression was associated with decreased CD1 gene expression.

KEY WORDS: squamous cell carcinoma cell line, 5-flourouracil, microvesicles, vascular endothelial growth factor, cyclin D1.

\footnotetext{
* Lecturer of Oral Pathology, Department of Oral Pathology, Faculty of Dentistry, Suez Canal University, Ismalia, Egypt ** Assitant professor of oral biology, Department of Oral Biology, Faculty of Dentistry, Cairo University

*** Professor of Medical Biochemistry and Molecular Biology, Department of Medical Biochemistry and molecular biology, Faculty of medicine, Cairo University
} 


\section{INTRODUCTION}

Globally, oral squamous cell carcinoma (OSCC) is the most common oral cancer; it arises from lip, cheek, floor of the mouth, tongue, gingiva and palate, with high mortality rate ${ }^{1}$. OSCC represents $90 \%$ of oral cancer, it is ordered as the sixth cancer among the common cancers worldwide ${ }^{2}$. OSCC has poor prognosis, because of late diagnosis and occurrence of metastasis at the time of its diagnosis ${ }^{3}$.

5-Fluorouracil (5-FU) is a widely used anticancer drug which was utilized as chemotherapeutic agent for head and neck tumors and gastrointestinal tumors ${ }^{4,5}$. Its mechanism of action is related to an anti-metabolic action via suppression of thymidylate synthase (TS) and incorporating its metabolites into RNA and DNA ${ }^{6}$.Although 5-FU, combined to other chemotherapeutic agents, increases response rates and survival in head and neck and breast cancers; however, 5-FU has had the greatest impact in colorectal cancer ${ }^{7}$. Nevertheless, response rates for 5-FU as a first-line chemotherapeutic treatment for progressive colorectal cancer are only 10$15 \%{ }^{8}$. The combination of $5-\mathrm{FU}$ with more recent chemotherapies such as irinotecan and oxaliplatin has enhanced the response rates in advanced colorectal cancer to reach $40-50 \%{ }^{9,10}$.Yet; despite these developments, new therapeutic approaches are necessarily needed.

Reports about the role of mesenchymal stem cells (MSCs) in tumor development and progression have been contradictory; where in 2009, Pinilla et al. ${ }^{11}$ demonstrated that MSCs, in co-culture in vitro experiments, stimulated the proliferation and invasion and of breast cancer cells. Besides, MSCs enhanced tumor growth and vascularization in an in vivo colorectal cancer xenograft model through increasing angiogenesis ${ }^{12}$. However, in addition to tumor progression, MSCs can also overwhelm tumor growth through decreasing proliferation and arresting cell cycle ${ }^{13}$. Anti-tumor properties are designated for MSCs derived from various sources in both in vivo and in vitro tumor models. For example, injection of MSCs in in-vivo models of hepatoma ${ }^{14}$, prostate cancer ${ }^{15}$ and pancreatic cancer ${ }^{16}$ has resulted in tumor suppression. Microvesicles (MVs) derived from various cells have been established as an essential component of cell-to-cell communication involved in tissue regeneration ${ }^{17}$, therefore they may contribute to the paracrine action of $\mathrm{MSCs}^{18}$.

MVs are nanometer-sized, membranous vesicles secreted from many cell types into their surrounding extracellular space and into body fluids. MVs and exosomes are also found in many fluids such as: synovial fluid ${ }^{19}$, amniotic fluid ${ }^{20}$, bronchoalveolar lavage $^{21}$, saliva $^{22}$, plasma $^{23}$ and cerebrospinal fluid ${ }^{24}$. MVs, also referred to as shedding vesicles, differ from exosomes in being larger in size, about 100$1000 \mathrm{~nm}$ in diameter. They are formed by budding off the plasma membrane into the extracellular space ${ }^{25}$, capturing the cellular cytosolic content in the newly formed lumen as well as plasma membrane receptors in the surrounding membrane ${ }^{26}$.

Hence, the aim of the present work was to investigate the impact of MSCs derived MVs, either alone or in combination to 5-FU, on chemosensitivity of SCC152 cell line, through histopathological examination as well as qRT-PCR analysis to detect vascular endothelial growth factor (VEGF) and cyclin D1 genes' expression in all studied groups. Finally, statistical analysis of the obtained data and correlation between VEGF and cyclin D1 genes' expression were also performed.

\section{MATERIAL AND METHODS}

\section{Cell Culture and Chemicals}

Human squamous cell carcinoma cell line (SCC152) was purchased from the American Type Culture Collection (ATCC, CRL-3240; Minnesota, USA,). It was cultured in Dulbecco's Modified Eagle's Medium (DMEM) and enriched with 10\% fetal bovine serum (FBS) and $1 \%$ concentration ratio of penicillin and streptomycin (Lonza, Verviers, Belgium). Culture of SCC152 cells were preserved 
in typical humidified incubator supplied with $5 \%$ $\mathrm{CO}_{2}, 95 \%$ air at $37^{\circ} \mathrm{C}$. 5-Fluorouracil was purchased from Sigma-Aldrich Chemical Co., St. Louis, Mo, U.S.A. MVs was prepared and derived from adipose mesenchymal stem cells. 5-Fluorouracil and MVs were freshly solubilized in phosphate buffer saline (PBS). Our studied groups were included: SCC152, SCC152+5-Fluorouracil, SCC152+MVs and SCC152+5-Fluorouracil +MVs.

\section{Microvesicles Isolation}

MSCs were obtained from supernatants of human adipose mesenchymal stem cells (hAMSCs). Briefly, hAMSCs were cultured in DMEM without FBS and with added $0.5 \%$ human serum albumin (HSA) (Sigma-Aldrich) overnight. The viability of the cell cultured overnight was $>99 \%$ as detected by trypan blue exclusion. The conditioned medium was collected and stored at $-80^{\circ} \mathrm{C}$. The medium was centrifuged at $2,000 \mathrm{~g}$ for $20 \mathrm{~min}$ to remove debris, and then ultracentrifuged at $100,000 \mathrm{~g}$ in a SW41 swing rotor (Beckman Coulter, Fullerton, CA, USA) for one hour at $4^{\circ} \mathrm{C}$. MVs were washed once with serum free M199 (SigmaAldrich) containing $25 \mathrm{mM}$ 4-(2-hydroxyethyl)-1piperazineethanesulfonic acid (HEPES) $(\mathrm{pH}=7.4)$ and submitted to a second ultracentrifugation in the same conditions. MVs were stored at $-80^{\circ} \mathrm{C}$ for the experiments. To quantify the protein content, the Bradford MVs were isolated from the ADSCs under non hypoxic or hypoxic condition ${ }^{27}$.

\subsection{Hematoxylin and Eosin Staining Protocol}

Following fixation in $96 \%$ ethanol for $12 \mathrm{~h}$, the SCC152 cells were rehydrated with graded series of decreasing ethanol concentrations, stained for 12 minutes with hematoxylin, washed with phosphatebuffered saline (PBS) for development of the blue color for $30 \mathrm{~min}$, and then incubated with eosin for another $30 \mathrm{sec}$. During the next stage, the cells were washed with PBS and dehydrated using a graded series of increasing concentrations of ethanol ${ }^{28}$.

\section{Real time PCR}

The effect of 5-FU and MVs on vascular endothelial growth factor (VEGF) and Cyclin D1 (CD1) gene's expression was assessed using real time PCR. SCC152 cells at $1 \times 10^{5}$ cell/well were grown in a 6 well plate at IC50 concentration of 5FU and MVs. Cells were washed with cold PBS, trypsinized, harvested and centrifuged. Cells were suspended in $200 \mu \mathrm{l}$ cold RNA lysis buffer with $5 \mu \mathrm{l}$ RNase $(20 \mu \mathrm{g} / \mathrm{ml})$ for $15 \mathrm{~min}$. The cells were chilled on ice and further subjected to RNA extraction and purification using Thermo Fisher Scientific Inc. Germany (GeneJET, Kit, \#K0732) following the manufacturer's instructions. The yield of total RNA obtained was determined at 260 and $280 \mathrm{~nm}$ using Beckman dual spectrophotometer. Gene's expressions were determined using real time PCR (StepOne, version 2.1, Applied biosystem, Foster city, USA). 1000ng of the total RNA from each sample were used for cDNA synthesis followed by PCR amplification cycles using SensiFAST ${ }^{\mathrm{TM}}$ SYBR ${ }^{\circledR}$ Hi-ROX One-Step Kit, catalog no.PI-50217 $\mathrm{V}$, UK. The thermal cycling profile was 15 minutes at $45^{\circ} \mathrm{C}$ for cDNA synthesis followed by 5 minutes at $95^{\circ} \mathrm{C}$ for reverse transcriptase inactivation and polymerase activation. PCR amplification 40 cycles were followed which consisted of 15 seconds DNA denaturation at $95^{\circ} \mathrm{C}, 20$ seconds primers annealing at $55^{\circ} \mathrm{C}$ and 30 second at $72^{\circ} \mathrm{C}$ for the amplification step. Changes in the expression of each target gene were normalized relative to the mean critical threshold (CT) values of 18s RNA housekeeping gene by the $\Delta \Delta \mathrm{Ct}$ method. Primer sequences for each gene were demonstrated in Table (1).

TABLE (1): Primers sequence of all studied genes

\begin{tabular}{|l|l|}
\hline Gene symbol & Primer sequence from 5' - 3' \\
\hline VEGF & F: GAGATGAGCT TCCTACAGCAC \\
& R: TCACCGCCTCGGCTTGTCACAT \\
\hline Cyclin D 1 & F: TGAACTACCTGGACCGCT \\
(CD1) & R: GCCTCTGGCATTTTGGAG \\
\hline 18sRNA & F: CAGCCACCCGAGATTGAGCA \\
& R: TAGTAGCGACGGGCGGGTG \\
\hline
\end{tabular}




\section{Statistical analysis:}

Data were coded and entered using the Statistical Package for the Social Science (SPSS) version 22. Data were summarized using mean and standard deviation. Comparisons between groups were done using analysis of variance (ANOVA) with multiple comparisons post hoc tests when comparing more than 2 groups. Comparison between the two durations within each group was done using paired sample $t$-test. Correlations between quantitative variables (VEGF and CD1) were done using Pearson correlation coefficient. ${ }^{29}$

\section{RESULTS}

\section{Histopathological results}

\section{Control Group:}

At 24 hours, the untreated cultured SCC152 cells were highly cohesive, irregularly shaped and viable with rare apoptotic bodies (Fig. 1a). Besides, following $48 \mathrm{hrs}$ in culture, many viable cells were observed with only few apoptotic bodies (Fig. 1b).

\section{5-FU Group:}

At 24 hours, examining cultured SCC152 cells treated with 5- FU presented decreased viable cells and some apoptotic bodies (Fig. 1c), while after $48 \mathrm{hrs}$ in culture, apparently increased apoptotic bodies with few viable cells could be noticed (Fig. 1d).

\section{MVs Group:}

At 24 hours, cohesive stellate shaped viable cells were observed and few apoptotic bodies (Fig. 1e). In addition, following $48 \mathrm{hrs}$ in culture, fewer viable cells were noticed and slightly increased apoptotic bodies (Fig. 1f).

\section{Combination Group:}

At 24 hours, examining SCC152 cells after 24hrs in culture revealed numerous apoptotic bodies and only few viable cells (Fig. 1g). After 48 hours in culture, abundant apoptotic bodies appeared among the cultured SCC152 while rarely viable cells could be observed (Fig. 1h).

\subsection{Quantitative RT-PCR and Statistical Results:}

Quantitative RT-PCR analysis revealed that in the control, MVs and combination groups, VEGF gene expression wasn't significantly different in $48 \mathrm{hrs}$ compared to $24 \mathrm{hrs}$ ( $\mathrm{p}$-values $=0.2,0.16$ and 0.56 respectively); while in the 5-FU group, significant decrease in VEGF expression occurred in 48hrs compared to $24 \mathrm{hrs}$ ( $\mathrm{p}$-value $=0.013$ ). Regarding the qRT-PCR results for cyclin D1; a statistically insignificant difference in $\mathrm{CD} 1$ gene expression between $48 \mathrm{hrs}$ and $24 \mathrm{hrs}$ in the control, 5-FU and combination groups ( $\mathrm{p}$ values $=0.5,0.09$ and 0.2 respectively); while in the MVs group, a significant decrease in CD1 gene expression occurred in 48hrs duration compared to $24 \mathrm{hrs}$ (p value $=0.02$ ) $($ Table 2 ) .

Comparing the mean values \pm SD of VEGF gene expression among the four studied groups showed that in 24hrs duration, no significant difference occurred between the control, 5-FU and MVs groups ( $\mathrm{p}$ value $>0.05$ ); while a statistically significant decrease in VEGF gene expression was noticed in the combination group compared to the control and MVs groups ( $p$-values $=0.01$ and 0.02 respectively). On the other hand, in $48 \mathrm{hrs}$ duration, a significant decrease in VEGF gene expression occurred in the 5-FU, MVs and combination groups compared to the control one (p-values $<0.001,0.002$ and $<0.001$ respectively) but there wasn't a significant difference between 5-FU, MVs and combination groups (p-value >0 .05) (Table 2\&Fig. 2).

Concerning the qRT-PCR results of CD1 in 24hrs duration; a statistically significant decrease in $\mathrm{CD} 1$ gene expression was observed in the 5-FU and combination groups compared to the control one $(\mathrm{p}$-value $=0.001)$, while no significant difference occurred between the MVs and control groups ( $\mathrm{p}$-value $=0.4)$. In addition, a significant increase in $\mathrm{CD} 1$ gene expression was observed in the MVs group compared to the 5 -FU one ( $\mathrm{p}$-value $=0.008$ ) but a statistically significant decrease in CD1 gene expression occurred in the combination group com- 


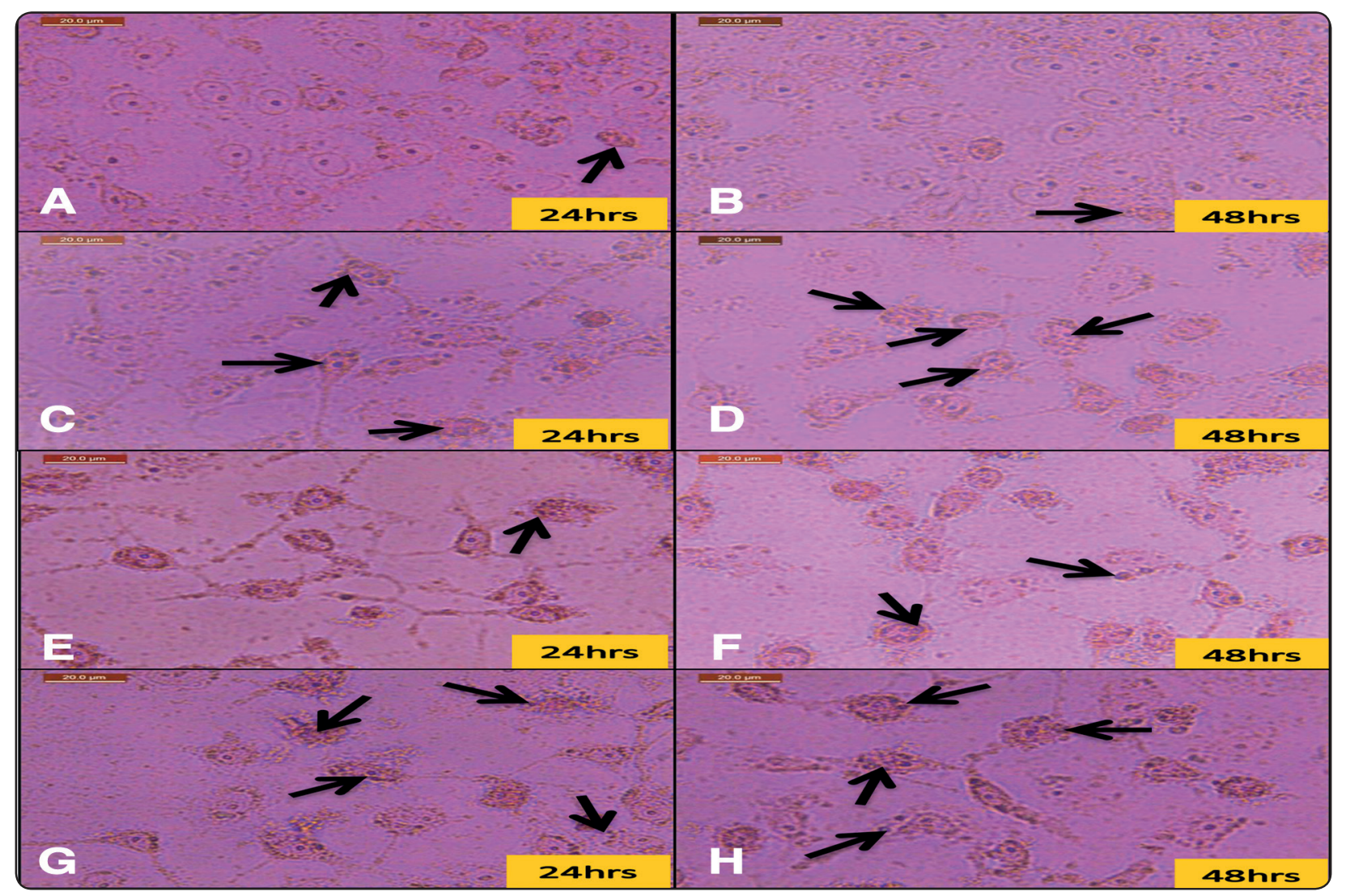

Fig. (1): Morphology of investigated SCC152 cells. Hematoxylin \& eosin staining (optical magnification $\times 400)(a \& b)$ Control group (a) at 24hrs of culture: highly cohesive irregularly shaped viable cells with rare apoptotic bodies (black arrow), (b) at $48 \mathrm{hrs}$ of culture: many viable cells with slightly increased apoptotic bodies (black arrows). (c\&d) 5-FU group (c) at 24hrs of culture: decreased viable cells and some apoptotic bodies (black arrows), (d) at $48 \mathrm{hrs}$ of culture: abundance of apoptotic bodies (black arrows) but few viable cells. (e\&f) MVs group (e) at $24 \mathrm{hrs}$ of culture: cohesive stellate shaped viable cells and few apoptotic bodies (black arrows), (f) at 48hrs of culture: fewer viable cells and slightly more apoptotic bodies. (g\&h) Combination group (g) at $24 \mathrm{hrs}$ of culture: numerous apoptotic bodies (black arrows) and only few viable cells, (h) at $48 \mathrm{hrs}$ of culture: increased apoptotic bodies (black arrows), and rarely viable cells.

pared to the MVs one ( $\mathrm{p}$ value 0.007). On the other hand, in $48 \mathrm{hrs}$ duration, there was a significant decrease in $\mathrm{CD} 1$ gene expression in the 5-FU, MVs and combination groups compared to the control one ( $\mathrm{p}$-values $=0.001,0.007$ and $<0.001$ respectively). However, no significant difference was noticed between the MVs, 5-FU and combination groups ( $\mathrm{p}$ value> 0.05) (Table 2\&Fig. 3).

Correlation between VEGF and CD1 revealed a very good positive correlation (p-value $<0.001 \&$ $\mathrm{r}=0.879$ ).

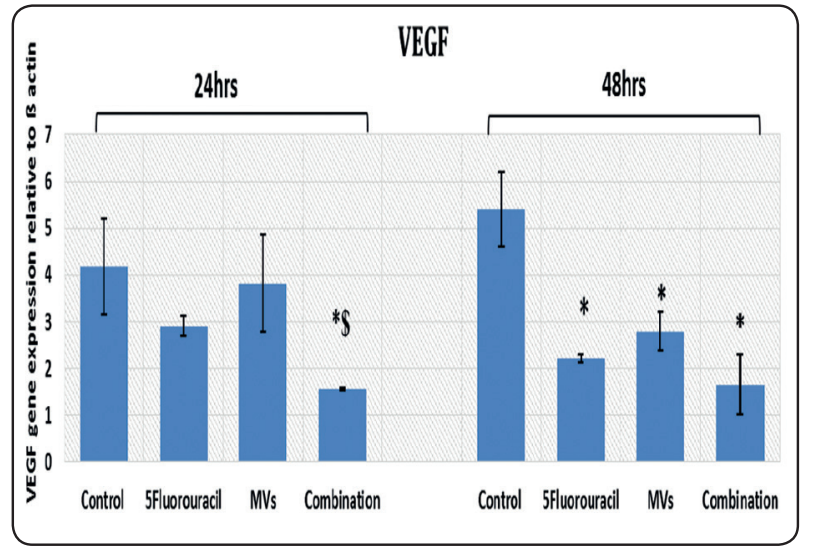

Fig. (2): A graph comparing mean \pm SD of VEGF gene expression among the four studied groups. Data were expressed as Mean $\pm \mathrm{SD}$, $\mathrm{p}$ value $<0.05$ was significant (*) Denotes significant difference versus control group (\#) Denotes significant difference versus 5-FLU group (\$) Denotes significant difference versus MVs group 


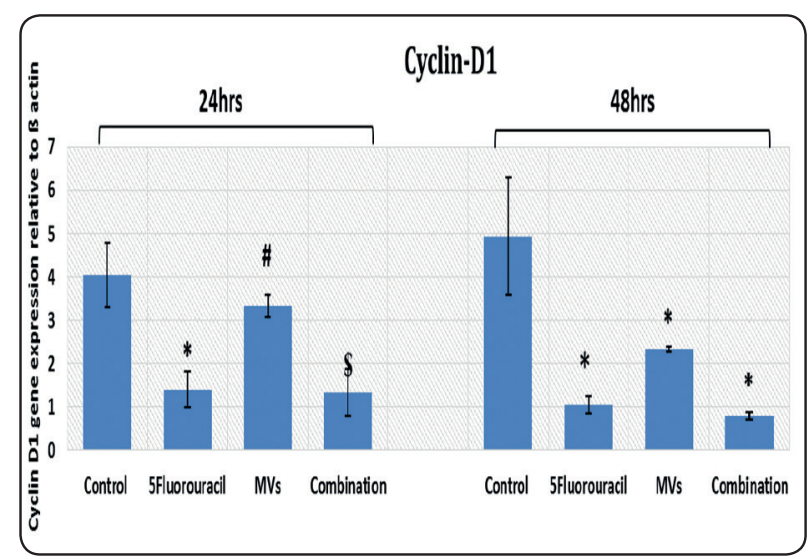

Fig. (3): A graph comparing mean \pm SD of Cyclin D1 gene expression among the four studied groups. Data were expressed as Mean $\pm \mathrm{SD}$, p value $<0.05$ was significant (*) Denotes significant difference versus control group

(\#) Denotes significant difference versus 5-FLU group

(\$) Denotes significant difference versus MVs group

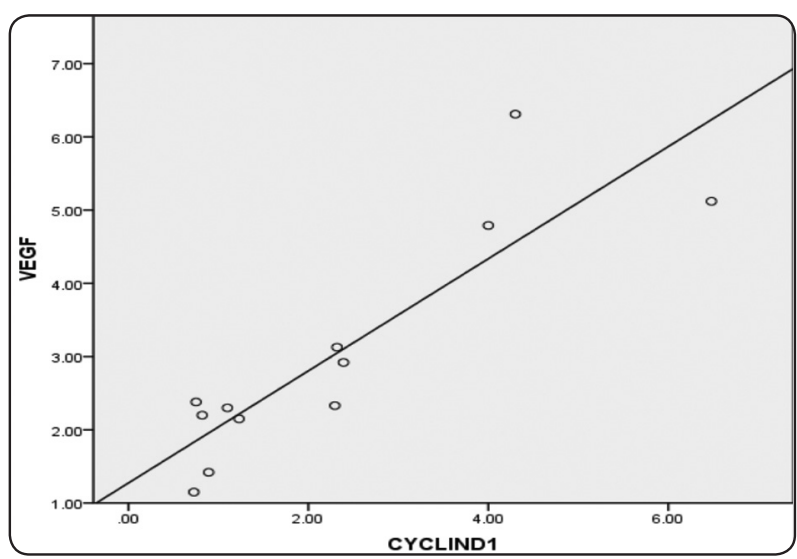

Fig. (4): A graph correlating between VEGF and Cyclin D1 genes' expressions, showing very good positive correlation between VEGF and Cyclin D1 (p-value $<0.001 \& \mathrm{r}=0.879$ ).

TABLE (2): Mean \pm SD values for VEGF and cyclin D1 genes expression among the four studied groups in 24 and 48 hrs durations.

\begin{tabular}{|c|c|c|c|c|c|c|c|}
\hline \multicolumn{4}{|c|}{ In $24 \mathrm{hrs}$} & \multicolumn{4}{|c|}{ In 48hrs } \\
\hline & & Mean & SD & & & Mean & SD \\
\hline \multirow{4}{*}{$\begin{array}{l}\text { 焉 } \\
\text { 至 }\end{array}$} & control & 4.17 & 1.03 & \multirow{4}{*}{$\begin{array}{l}\frac{5}{5} \\
\frac{1}{7}\end{array}$} & control & 5.40 & .79 \\
\hline & 5-FLU & 2.90 & .21 & & 5-FLU & 2.21 & .07 \\
\hline & MVs & 3.82 & 1.03 & & MVs & 2.79 & .41 \\
\hline & Combination & 1.55 & .032 & & Combination & 1.65 & .64 \\
\hline \multirow{4}{*}{ 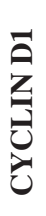 } & control & 4.04 & .75 & \multirow{4}{*}{$\begin{array}{l}\overline{\mathbf{Z}} \\
\mathbf{z} \\
\bar{z}\end{array}$} & control & 4.92 & 1.35 \\
\hline & 5-FLU & 1.40 & .40 & & 5-FLU & 1.05 & .20 \\
\hline & MVs & 3.33 & .25 & & MVs & 2.33 & .04 \\
\hline & Combination & 1.34 & .54 & & Combination & .78 & .08 \\
\hline
\end{tabular}

\section{DISCUSSION}

In 2012, cancers of the lip and oral cavity represented about $2.1 \%$ of the world total, with two thirds taking place in men. The region with the utmost incidence among both males and females was by far Melanesia. Rates were likewise quite high in men in South-Central Asia (9.9) and in Central and Eastern Europe (9.1). About145, 000 deaths occurred worldwide, of which $77 \%$ occurred in the less developed regions ${ }^{1}$. More recently, cancer is considered the global reason of deaths more than all other disease ${ }^{30}$ where a new estimation made by the WHO, in 2018, for thirty six cancer types in 185 countries, revealed that the number of cases of lip and oral cavity cancers were $(354,864)$ cases, 246,420 cases occurred in males, while females were less in number $(108,444)$ and deaths were $(177,384)$. Besides, oral cavity cancers are the most frequent type in South Asia. ${ }^{31}$ OSCC begins by oral epithelial dysplasia, where the epithelial cells 
show atypia and dysplastic changes of the tissue itself $^{32,33}$, then disruption of the basement membrane ,which is followed by invasion of tumor cells into the surrounding stroma ,causing reactive changes within the stroma ${ }^{34}$, the biological behavior of the tumor cells is not only governed by the genetic of the tumor cells but also by the tumor microenvironment which allows progression of the tumor cells, as an outcome of the imperfect response of both epithelial and stromal components ${ }^{35}$.

5-FU is widely used in the treatment of cancer where it causes suicidal inhibition, through irreversible hindering of thymidylate synthase inside the cells, which leads to overwhelming of DNA replication and thymineless cell loss ${ }^{36}$.Over the past 20 years, increased understanding of the mechanism of action of 5-FU has led to the development of strategies that increase its anticancer activity. Despite these advances, drug resistance remains a significant limitation to the clinical use of 5-FU ${ }^{6}$. Moreover, 5-FU use has many drawbacks, as its use is accompanied by cardiotoxicity ${ }^{37}$, fatigue, bleeding, decreased immunity, lowered blood count, diarrhea, mouth sores, hair loss, nausea, and vomiting ${ }^{38,39}$, in addition to the short half-life of 5-FU ${ }^{40}$.

Owing to the previously mentioned limitations of 5-FU use; the current study was conducted to explore the potential benefit of using MVs either alone or in combination to 5-FU in an attempt to minimize the damaging effects of prolonged use of 5-FU while increasing its anti-cancerous effect.

Based on clinical trials, mesenchymal stem cells (MSCs)-based treatment is considered rather safe, and according to our knowledge, no significant damaging effects have been described in humans. However, there are some concerns about the use of reproducing cells that may be out of control along time ${ }^{41}$. Preclinical studies suggested that abnormal differentiation of injected MSCs could occur. Besides, calcification of the myocardium ${ }^{42}$ and increased accumulation of fibroblasts and myofibroblasts in the lungs ${ }^{43}$ have been described after treatment with MSCs. As MVs hold several biological properties of the cell of origin, the development of therapeutic strategies that avoid the administration of MSCs can be imagined. This may attenuate many of the safety concerns related to the use of living cells ${ }^{41}$. Thus, the use of MVs could have advantages related to the use of soluble factors, the favorable effects of which are restricted by their difficult delivery to the suitable cell type ${ }^{41}$.

Extracellular vesicles have been lately considered as key mediators of cell-to-cell communication. They can be categorized into exosomes and shedding vesicles. Exosomes originate from the endosomal membrane cell compartment then released into the extracellular space following fusion of the plasma membrane with multivesicular bodies. Shedding vesicles arise from direct budding of the plasma membrane of different cell types and are more heterogeneous in size $(100 \mathrm{~nm}-1 \mu \mathrm{m})^{44,45}$. Since both, exosomes and shedding vesicles, are found in vivo and in vitro, this diverse population is collectively called $\mathrm{MVs}^{18}$. MVs from various cells contain nucleic acids involving mRNA and microRNA in addition to biologically active functional protein $\mathrm{s}^{46}$.

In the current study, histopathological examination of cultured SCC152 cells showed numerous highly cohesive irregular cells in the untreated group with rare apoptotic bodies, while following treatment with 5-FU, an obvious decrease occurred in viable cells and appearance of apoptotic bodies which increased at $48 \mathrm{hrs}$ of culture. In the MVs treated group, cohesive stellate shaped viable cells could be still noticed, with few apoptotic bodies which slightly increased at $48 \mathrm{hrs}$ of culture, while in the combination group, numerous apoptotic bodies were detected at $24 \mathrm{hrs}$ and were obviously increased at $48 \mathrm{hrs}$ of culture where viable cells were rarely seen.

The obvious improvement noticed in the combination group could be attributed to the additional anticancerous effect of MVs. The current results are in consistence with various studies 
demonstrating the anti-tumor effect of MVs. For example, in (2009) Sarkar et al. demonstrated that MVs derived from lipopolysaccharideactivated monocytes could induce apoptosis in target cells through caspase- 1 transfer ${ }^{47}$. In another study, in (2015) Del Fattore et al. ${ }^{48}$ reported that MVs derived from cord blood and bone marrowderived MSCs inhibited division and stimulated apoptosis in glioblastoma cells. Besides, Yuan et al. demonstrated the antitumor activity of MSCsderived MVs loaded with recombinant tumor necrosis factor-related apoptosis-inducing ligand (rTRAIL) on their surface. In the presence of MVs, apoptosis was induced in cultured breast cancer cells. Besides, MVs did not cause apoptosis in normal human bronchial epithelial cells. Hence, the use of MSCs-derived MVs carrying rTRAIL on their surface was proven to be more efficient than using pure rTRAIL ${ }^{49}$.

On the contrary, MVs derived from adipose MSCs induced proliferation of tumor cells ${ }^{48}$. Additionally, MSC-derived MVs can enhance tumor cell resistance to chemotherapeutic drugs owing to the micro-RNAs included in the $\mathrm{MVs}^{50}$. Thus, there are contradictory reports about the role of MSCs derived MVs in tumor development and progression and such differences might be attributed to the activation state of parental MSCs from which the MVs are derived ${ }^{51}$.

Regarding the qRT-PCR results of VEGF gene expression, comparing all studied groups revealed that in the control, MVs and combination groups, VEGF gene expression wasn't significantly different in $48 \mathrm{hrs}$ compared to $24 \mathrm{hrs}$; while in the $5-\mathrm{FU}$ group, a significant decrease occurred in $48 \mathrm{hrs} \mathrm{com-}$ pared to $24 \mathrm{hrs}$. In addition, at $24 \mathrm{hrs}$ duration, no significant difference occurred between the control, 5-FU and MVs groups; while a significant decrease was noticed in the combination group compared to the control and MVs groups. On the other hand, in 48hrs duration, a significant decrease occurred in the 5-FU, MVs and combination groups compared to the control one but there wasn't a significant difference between 5-FU, MVs and combination groups.
Concerning the qRT-PCR results for cyclin D1gene expression; there was an insignificant difference between $48 \mathrm{hrs}$ and $24 \mathrm{hrs}$ in the control, 5-FU and combination groups; while in the MVs group, a significant decrease occurred in $48 \mathrm{hrs} \mathrm{du}$ ration compared to $24 \mathrm{hrs}$. Comparing all studied groups revealed that; at $24 \mathrm{hrs}$ duration, a significant decrease was observed in the 5-FU and combination groups compared to the control one, while no significant difference occurred between the MVs and control groups. In addition, a significant increase was observed in the MVs group compared to the 5-FU one but a significant decrease occurred in the combination group compared to the MVs one. On the other hand, in $48 \mathrm{hrs}$ duration, there was a significant decrease in the 5-FU, MVs and combination groups compared to the control one. However, no significant difference was noticed between the MVs, 5-FU and combination groups. Furthermore, a very good positive correlation occurred between VEGF and CD1 genes' expression. The obtained statistical results obviously supported the current histopathological findings, where both VEGF and CD1 genes' expressions were apparently down regulated in the combination group than either 5-FU or MVs treated groups. This, in turn, back up the advantageous effect of simultaneous treatment of SCC 152 cells with MVs and 5-FU compared to using 5-FU alone.

Angiogenesis is one of the most important biological processes for tumor progression, growth and metastasis ${ }^{52}$, this process is governed by many genetic and biochemical mechanisms including: fibroblast growth factor, transforming growth factor-beta and vascular endothelial growth factor $\mathrm{VEGF}^{53}$. The later, being one of the most essential angiogenic factors, acts through inducing endothelial cell proliferation, survival, and vascular maturation ${ }^{54}$. VEGF was shown to play an important role in the angiogenesis of $\mathrm{OSCC}^{55}$ and it has been recently considered, together with $\mathrm{CD} 1$, to be useful prognostic biomarkers for oral tongue squamous cell carcinoma ${ }^{56}$. In turn, in the herein study, VEGF and CD1 gene expressions were analyzed, statistically compared and correlated among all studied groups. 
The current results revealed increased expression of VEGF gene in untreated SCC152 group while it was decreased in 5-FU, MVs and combination groups. These results are in accordance with those of Singhal et al. (2016) who demonstrated that, in cancer mucosa, VEGF is significantly overexpressed when compared to normal mucosa. The authors concluded that overexpression of VEGF was accompanied with chemo-resistance, thus; it may serve as a negative predictive marker. ${ }^{57}$

The well-ordered progression of cells through several phases of cell cycle (G1, S, G2, and M phases) is accurately directed by a group of proteins called "cyclins," which bind and activate cyclindependent kinases. Cyclin D1, a 45 kilo dalton protein encoded by cyclin D1 gene and represents a part of the molecular system regulating the cell cycle $\mathrm{G} 1$ to $\mathrm{S}$ transition ${ }^{58}$. Overexpression of $\mathrm{CD} 1$ was related to the development and progression of cancer ${ }^{59}$.

In the present work, the expression of CD1 gene was enhanced in the SCC152 group than in the 5-FU, MVs and combination groups. These results could be supported by previous observations of Yu et al.(2005) who reported an overexpression of CD1 in head and neck squamous cell carcinoma, so, it could be a valuable prognostic marker in oropharyngeal squamous cell carcinoma ${ }^{60}$. Additionally, CD1 showed degradation following therapeutic anti-cancer agents use. This again could clarify the decreased expression of CD1 in 5-FU and combination groups.

Remarkably, a very good positive correlation existed between VEGF and CD1 genes' expression. This correlation could be supported by the previous findings of Llan et al.(2003), who reported that VEGF induced increased expression of CD1 and enhanced cell proliferation in hemangioma-derived cell line and primary human endothelial cells cultures, while applying an anti-VEGF neutralizing antibody in in the same cultures resulted in inhibition of both CD1 expression and cell proliferation ${ }^{61}$.
Furthermore, in a study by Yasui et al.,(2006) they concluded that CD1 not only played a role in sustaining VEGF expression but also improved the functions of VEGF within the epithelial cells to enhance tumor vascularization ${ }^{62}$.

Finally, according to the current results, it could be concluded that treating SCC152 with 5-FU or MVs or their combination has resulted in increased apoptotic bodies and decreased viable cells, which was most obvious in the combination group and more pronounced at $48 \mathrm{hrs}$ compared to $24 \mathrm{hrs}$. Moreover, VEGF and CD1 genes' expression was down regulated following treatment with 5-FU or MVs or their combination, which again was markedly noticed in the combination group most. Correlating VEGF and CD1 genes' expression has revealed a very good positive correlation and thus, these two genes could be useful predictor markers for the progression and prognosis of SCC.

\section{CONCLUSION}

Despite the fact that diagnosis and treatment approaches were improved, mortality caused by oral cancers is still high. And since simultaneous use of MVs and 5-FU together in treating SCC has resulted in a remarkable reduction of viable cancer cells, increased apoptotic cell death and decreased VEGF and CD1 genes' expressions; thus, MVs represent a valuable alternative to using MSCs themselves and they can also be modified to deliver anti-tumor agents without taking the risk of using intact MSCs which; in addition to having anti-cancer properties, also have pro-oncogenic properties.

\section{RECOMMENDATION}

Preclinical animal studies and clinical trials are still needed to evaluate the long-term safety of MVs use. In addition, expression of VEGF and CD1 genes could be useful as predictive makers of tumor progression. 


\section{REFERENCES}

1. Ferlay J, Soerjomataram I, Dikshit R, Eser S, Mathers C, Rebelo M, Parkin DM, Forman D, Bray F. Cancer incidence and mortality worldwide: sources, methods and major patterns in GLOBOCAN 2012. Int J cancer. 2015; 136(5):E359-86.

2. Radhika T, Jeddy N, Nithya S, Muthumeenakshi RM. Salivary biomarkers in oral squamous cell carcinoma - An insight. J Oral Biol Craniofac Res. 2016;6(Suppl 1):S51-S4.

3. Forastiere A, Koch W, Trotti A, Sidransky D. Head and neck cancer. N Engl J Med. 2001 ;345(26):1890-900.

4. Grem JL. 5-Fluorouracil: forty-plus and still ticking. A review of its preclinical and clinical development. Invest New Drugs. 2000;18(4):299-313.

5. Myers CE. The pharmacology of the fluoropyrimidines. Pharmacol Rev. 1981;33(1):1-15.

6. Longley DB, Harkin DP, Johnston PG. 5-fluorouracil: mechanisms of action and clinical strategies. Nat Rev Cancer. 2003;3(5):330-8.

7. No authors listed. Efficacy of adjuvant fluorouracil and folinic acid in colon cancer. International Multicentre Pooled Analysis of Colon Cancer Trials (IMPACT) investigators. Lancet. 1995;345 (8955):939-44.

8. Johnston PG, Kaye S. Capecitabine: a novel agent for the treatment of solid tumors. Anticancer Drugs 2001; 12(8):639-46.

9. Giacchetti S, Perpoint B, Zidani R, Le Bail N, Faggiuolo R, Focan C. Chollet P, Llory JF, Letourneau Y, Coudert B, Bertheaut-Cvitkovic F, Larregain-Fournier D, Le Rol A, Walter S, Adam R, Misset JL, Lévi F. Phase III multicenter randomized trial of oxaliplatin added to chronomodulated fluorouracil leucovorin as first-line treatment of metastatic colorectal cancer. J. Clin. Oncol. 2000; 18(1):136-47.

10. Douillard JY, Cunningham D, Roth AD, Navarro M, James RD, Karasek PJandik P, Iveson T, Carmichael J, Alakl M, Gruia G, Awad L, Rougier P. Irinotecan combined with fluorouracil compared with fluorouracil alone as first-line treatment for metastatic colorectal cancer: a multicentre randomised trial. Lancet 2000; 355 (9209): 1041-7.

11. Pinilla S, Alt E, Abdul Khalek FJ, Jotzu C, Muehlberg F, Beckmann C, Song YH. Tissue resident stem cells produce CCL5 under the influence of cancer cells and thereby promote breast cancer cell invasion. Cancer Lett. 2009; 284(1): 80-5.
12. Huang WH, Chang MC, Tsai KS, Hung MC, Chen HL, Hung SC. Mesenchymal stem cells promote growth and angiogenesis of tumors in mice. Oncogene 2013; 32(37): 4343-54.

13. Ramdasi S, Sarang S, Viswanathan C. Potential of mesenchymal stem cell based application in cancer. Int. J. Hematol. Oncol. Stem Cell Res.2015; 9(2): 95-103.

14. Qiao L, Xu Z, Zhao T, Zhao Z, Shi M, Zhao RCYe L, Zhang X..Suppression of tumorigenesis by human mesenchymal stem cells in a hepatoma model. Cell Res. 2008; 18(4): 500-7.

15. Chanda D, Isayeva T, Kumar S, Hensel JA, Sawant A, Ramaswamy G, Siegal GP, Beatty MS, Ponnazhagan S Therapeutic potential of adult bone marrow-derived mesenchymal stem cells in prostate cancer bone metastasis. Clin. Cancer Res. 2009; 15(23): 7175-85.

16. Doi, C., Maurya, DK, Pyle MM, Troyer D, Tamura M. Cytotherapy with naive rat umbilical cord matrix stem cells significantly attenuates growth of murine pancreatic cancer cells and increases survival in syngeneic mice. Cytotherapy $2010 ; 12(3)$ : 408-17.

17. Camussi G, Deregibus MC, Bruno S, Cantaluppi V, Biancone L. Exosomes/microvesicles as a mechanism of cellto-cell communication. Kidney Int 2010; 78(9):838-48.

18. Biancone L, Bruno S, Deregibus MC, Tetta C, Camussi G. Therapeutic potential of mesenchymal stem cellderived microvesicles. Nephrol Dial Transplant. 2012; 27(8):3037-42.

19. Skriner K, Adolph K, Jungblut PR, Burmester GR. Association of citrullinated proteins with synovial exosomes. Arthritis Rheum. 2006; 54(12):3809-14.

20. Keller S, Rupp C, Stoeck A, Runz S, Fogel M, Lugert S , Hager HD, Abdel-Bakky MS, Gutwein P,Altevogt P,CD24 is a marker of exosomes secreted into urine and amniotic fluid. Kidney Int. 2007; 72 (9): 1095-102.

21. Prado, N., Marazuela, E. G., Segura, E., Fernandez-Garcia, H. Villalba M Théry C, Rodríguez R, Batanero E. Exosomes from bronchoalveolar fluid of tolerized mice prevent allergic reaction. J. Immunol. 2008; 181 (2): 1519-25.

22. Gonzalez-Begne M, Lu B, Han X, Hagen FK, Hand AR, Melvin JE, Yates JR.Proteomic analysis of human parotid gland exosomes by multidimensional protein identification technology (MudPIT). J. Proteome Res. 2009; 8(3):1304-14. 
23. Grant R, Ansa-Addo E, Stratton D, Antwi-Baffour S, Jorfi S, Kholia SKrige L, Lange S, Inal J. A filtration-based protocol to isolate human plasma membrane-derived vesicles and exosomes from blood plasma. J. Immunol. Methods 2011; $371(1-2):: 143-51$.

24. Street JM, Barran PE, Mackay CL, Weidt S, Balmforth C, Walsh TS Chalmers RT, Webb DJ, Dear JW.Identification and proteomic profiling of exosomes in human cerebrospinal fluid. J. Transl. Med. 2012; 10: 5.

25. Thery C, Ostrowski M, Segura E. Membrane vesicles as conveyors of immune responses. Nat. Rev. Immunol. 2009; 9(8):581-93.

26. Kahner BN, Dorsam RT, Kunapuli SP. Role of P2Y receptor subtypes in platelet-derived microparticle generation. Front. Biosci. 2008; 13: 433-9.

27. Kang T, Jones TM, Naddell C, Bacanamwo M, Calvert JW, Thompson WE, Bond VC, Chen YE, Liu D. AdiposeDerived Stem Cells Induce Angiogenesis via Microvesicle Transport of miRNA-31. Stem Cells Translational Medicine 2016; 5 (4):440-50.

28. Dziedzic A, Kubina R, Kabała-Dzik A, Wojtyczka RD, Morawiec T, Bułdak RJ. Caffeic acid reduces the viability and migration rate of oral carcinoma cells (SCC25) exposed to low concentrations of ethanol. Int. J. Mol. Sci. 2014; 15(10): 18725-41.

29. Chan Y. Biostatistics 102: Quantitative Data - Parametric \& Non-parametric Tests. Singapore Med J. 2003; 44(8):391-6.

30. World Health Organization. Global Health Observatory. Geneva: World Health Organization; 2018. who.int/gho/ database/ en/. Accessed June 21, 2018.

31. Bray F, Ferlay J, Soerjomataram I, Siegel RL, Torre LA, Jemal A. Global cancer statistics 2018: GLOBOCAN estimates of incidence and mortality worldwide for 36 cancers in 185 countries. CA Cancer J Clin. 2018; 68(6):394-424.

32. Speight PM. Update on oral epithelial dysplasia and progression to cancer. Head and Neck Pathol. 2007; 1(1):61-6.

33. Jayaraj G, Ramani P, Herald J, Kumar P, Anuja N. Interobserver agreement in grading oral epithelial dysplasia a systematic review. J Oral Maxillofac Surg Med Pathol. 2015; 27(1):112-6.

34. Fuentes B, Duaso J, Droguett D, Castillo C, Donoso W, Rivera C . Venegas B., Kemmerling U. Progressive extracellular matrix disorganization in chemically induced murine oral squamous cell carcinoma. ISRN Pathol. 2012; 359421:1-7.

35. Astekar M, Metgud R, Sharma A, Soni A. Hidden keys in stroma: unlocking the tumor progression. J Oral Maxillofac Pathol. 2013; 17(1):82-8.

36. Arias JL. Novel strategies to improve the anticancer action of 5-fluorouracil by using drug delivery systems. Molecules. 2008; 13(10):2340-69.

37. Anand AJ. Fluorouracil cardiotoxicity. Ann Pharmacother 1994; 28(3):374-8.

38. Ratajczak MZ, Jadczyk T, Schneider G, Kakar SS, Kucia M. Induction of a tumor-metastasis-receptive microenvironment as an unwanted and underestimated side effect of treatment by chemotherapy or radiotherapy. J Ovarian Res. 2013; 6(95):2-9.

39. Sun J, Wei Q, Zhou Y, Wang J, Liu Q, Xu H. A systematic analysis of FDA-approved anticancer drugs. BMC Syst Biol. 2017; 11(87):27-43.

40. Gao Z, Li Z, Yan J, Wang P. Irinotecan and 5-fluorouracil-co-loaded, hyaluronic acid-modified layer-by-layer nanoparticles for targeted gastric carcinoma therapy. Drug Des Devel Ther. 2017; 11:2595-604.

41. Lai RC, Chen TS, Lim SK. Mesenchymal stem cell exosome: a novel stem cell-based therapy for cardiovascular disease. Regen Med 2011; 6(4):481-92.

42. Breitbach M, Bostani T, Roell W, Xia Y, Dewald O, Nygren JM, Fries JW, Tiemann K, Bohlen H, Hescheler J, Welz A, Bloch W, Jacobsen SE, Fleischmann BK. Potential risks of bone marrow cell transplantation into infarcted hearts. Blood 2007; 110(4) :1362-69.

43. Epperly MW, Guo H, Gretton JE, Greenberger JS. Bone marrow origin of myofibroblasts in irradiation pulmonary fibrosis. Am J Respir Cell Mol Biol 2003; 29(2):213-24.

44. Mathivanan S, Ji H, Simpson RJ. Exosomes: extracellular organelles important in intercellular communication. J Proteomics 2010; 73(10):1907-20.

45. György B, Szabó TG, Pásztói M, Pál Z, Misják P, Aradi B, László V, Pállinger E, Pap E, Kittel A, Nagy G, Falus A, Buzás EI. Membrane vesicles, current state-of-the-art: emerging role of extracellular vesicles. Cell Mol Life Sci 2011; 68 (6):2667-88.

46. Pokharel D, Wijesinghe P, Oenarto V, Lu JF, Sampson DD, Kennedy BF, Wallace VP, Bebawy M. Deciphering 
cell-to-cell communication in acquisition of cancer traits: extracellular membrane vesicles are regulators of tissue biomechanics. OMICS 2016; 20 (8): 462-69.

47. Sarkar A, Mitra S, Mehta S, Raices R, Wewers MD. Monocyte derived microvesicles deliver a cell death message via encapsulated caspase-1. PLoS One 2009; 4:e7140.

48. Del Fattore A, Luciano R, Saracino R, Battafarano G, Rizzo C, Pascucci L, Alessandri G, Pessina A, Perrotta A, Fierabracci A, Muraca M.Differential effects of extracellular vesicles secreted by mesenchymal stem cells from different sources on glioblastoma cells. Expert Opin. Biol. Ther. 2015; 15 (4):495-504.

49. Yuan Z, Kolluri KK, Gowers KH Janes SM. TRAIL delivery by MSC-derived extracellular vesicles is an effective anticancer therapy. J. Extracell. Vesicles 2017; 6(1):1265291.

50. Bliss SA, Sinha G, Sandiford OA, Williams LM, Engelberth DJ, Guiro K, Isenalumhe LL, Greco SJ, Ayer S, Bryan M Kumar R, Ponzio NM, Rameshwar P. Mesenchymal stem cell-derived exosomes stimulate cycling quiescence and early breast cancer dormancy in bone marrow. Cancer Res. 2016; 76(19): 5832-44.

51. Chulpanova DS, Kitaeva KV, Tazetdinova LG, James V, Rizvanov AA, Solovyeva VV. Application of Mesenchymal Stem Cells for Therapeutic Agent Delivery in Antitumor Treatment. Front Pharmacol. 2018; 20:9:259.

52. Hasina R, Lingen MW. Angiogenesis in oral cancer. J Dent Educ 2001; 65(11):1282-90.

53. Dodelet VC, Pasquale EB. Eph receptors and ephrin ligands:Embryogenesis to tumorigenesis. Oncogene 2000; 19(49):5614-9.

54. Zafirellis K, Agrogiannis G, Zachaki A, Gravani K, Karameris A, Kombouras C. Prognostic significance of VEGF expression evaluated by quantitative immunohistochemi- cal analysis in colorectal cancer. J Surg Res 2008; 147(1): 99-107.

55. Kim SK, Park SG, Kim KW. Expression of vascular endothelial growth factor in oral squamous cell carcinoma. J Korean Assoc Oral Maxillofac Surg. 2015; 41(1):11-8.

56. Almangush A, Heikkinen I, Mäkitie AA, Coletta RD, Läärä E, Leivo I, Salo T. Prognostic biomarkers for oral tongue squamous cell carcinoma: a systematic review and meta-analysis. Br J Cancer. 2017; 117(6):856-66.

57. Singhal A, Hadi R, Chaturvedi A, Sharma ID, Misra S and Husain N. Vascular endothelial growth factor expression in oral cancer and its role as a predictive marker: A prospective study. Saudi Surg J 2016; 4 (2): 52-56.

58. Angadi PV, Krishnapillai R. "CyclinD1 expression in oral squamous cell carcinoma and verrucous carcinoma: correlation with histological differentiation. Oral Surgery, Oral Medicine, Oral Pathology, Oral Radiology and Endodontology 2007; 103(3):e30-e35.

59. Alao JP. The regulation of cyclin D1 degradation: roles in cancer development and the potential for therapeutic invention. Mol Cancer. 2007;6: 24.

60. Yu Z, Weinberger PM, Haffty BG, Sasaki C, Zerillo C, Joe J, Kowalski D, Dziura J, Camp RL, Rimm DL, Psyrri A.. Cyclin $\mathrm{d} 1$ is a valuable prognostic marker in oropharyngeal squamous cell carcinoma. Clin Cancer Res 2005; 11 (3):1160-6.

61. Ilan N, Tucker A, Madri JA. Vascular endothelial growth factor expression, beta-catenin tyrosine phosphorylation, and endothelial proliferative behavior: a pathway for transformation? Lab Invest.2003; 83(8):1105-15.

62. Yasui M, Yamamoto H, Ngan CY, Damdinsuren B, Sugita Y, Fukunaga H Gu J, Maeda M, Takemasa I, Ikeda M, Fujio Y, Sekimoto M, Matsuura N, Weinstein IB, Monden M. Antisense to cyclin D1 inhibits VEGF-stimulated growth of vascular endothelial cells: Implication of tumor vascularization. Clin Cancer Res 2006; 12(15):4720-9. 